\title{
Partial root-zone drying (PRD), its effects and agricultural significance: a review
}

\author{
Rashid lqbal ${ }^{1 *}$ D, Muhammad Aown Sammar Raza', Monika Toleikiene², Muhammad Ayaz ${ }^{2}$, Fatemeh Hashemi ${ }^{3}$, \\ Muhammad Habib-ur-Rahman ${ }^{4,5}$, Muhammad Saqlain Zaheer ${ }^{1}$, Salman Ahmad ${ }^{1}$, Umair Riaz ${ }^{6}$, Muhammad Ali', \\ Muhammad Usman Aslam ${ }^{1}$ and Imran Haider ${ }^{1}$
}

\begin{abstract}
Background: Water resources are very important to agricultural crop production due to increasing demand for food, feed, and fiber. There is a growing requirement for more use of our natural resources of land, soil, and water. There is ever-increasing pressure on water resources for our extensive use in agricultural production. There needs to be innovative solutions for more efficient irrigation techniques for better development of agricultural irrigation management.

Main body of the abstract: This review paper shows the consequences of partial root-zone drying happening on various plant species, its advantages and disadvantages, and also the hormone production under partial root-zone drying. In this technique of irrigation, a wet-dry cycle irrigates the crop, i.e., irrigation is scheduled at a regular interval with half way root drying.

Short conclusion: This is a water-saving irrigation strategy used in arid and semi-arid environments for increasing irrigation water use efficiency and water productivity as compared to fully irrigated crop plants in area with limited water resources. Scientists have worked a lot with different morphological, physiological, and yield related parameters of horticultural crops with partial root-zone drying but little work with agronomic crops.
\end{abstract}

Keywords: Partial root drying (PRD), Abscisic acid (ABA), Different irrigation levels, Crops and tree species, Water use efficiency (WUE)

\section{Background}

Many environmental factors affect the plant growth, yield, and quality, and the most prominent is drought (Sinclair 2005; Tawfik and El-Mouhamady 2019). Scarcity of water mostly affected growth and yield-related parameters of various crops (Raza et al. 2012a; Tawfik and El-Mouhamady 2019). Production losses due to drought are the most relative comparing with any other abiotic or biotic factors (Bakht et al. 2010; Castillo et al. 2007; Khan et al. 2010). All the physiological and yield-related aspects of a crop were severely affected by drought from the very early stage of seedling to harvesting (Chaves and Oliveira 2004). Drought

\footnotetext{
* Correspondence: scorpio.rana786@gmail.com

'Department of Agronomy, University College of Agriculture \& Environmental Sciences, The Islamia University of Bahawalpur, Bahawalpur, Pakistan

Full list of author information is available at the end of the article
}

affects the plants at every stage, i.e., internal functions, processes, physical appearance of plants, and production (Jones et al. 2003; Raza et al. 2012a; Gholipoor et al. 2013; Tawfik and El-Mouhamady 2019).

The world population is increasing at an alarming rate, so there may be deficiency of feed, fiber, and food for humans and animals. With this swift increase in population, there are also chances of increasing drought (Wilhite and Smith 2005). Now, it is necessary to choose the most appropriate methods and strategies to compensate for this drought stress. Selecting the most economic and suitable water irrigation for each specific purpose is an outstanding way to manage the drought problem (Nasrullah et al. 2011). Various methods have been used, e.g., use of different nutrients (either micro or macro) (Raza et al. 2012b), numerous solutes levels (Raza et al. 2012c; Sadak et al. 2020), and agronomic practice, like mulching (Kader et al. 
2019; Iqbal et al. 2020), to prevail over insufficient water situations (Schahbazian and Iran-Nejad 2006). Although these techniques can minimize the damaging effects of drought but most of these are expensive, time consuming, or require specific machinery which is only afforded by a limited number of farmers, as most of the farmers in arid and semi-arid regions are subsistent. Moreover, water crisis, energy crisis, and a higher rate of inputs are the major hurdles for adopting these anti-drought strategies by farmers. Henceforth, we need to develop a management technique which not only minimizes water use without a major reduction in crop yield but is both economical and easily approachable by the farmers.

Many investigations have been carried out in order to improve irrigation systems, water use efficiency, and productivity. However, many researches in both less and efficient water consumption are at a standstill (Sleper et al. 2007). Some growers are still using flood irrigation even if the water is plentiful or not. This method provides the crop plants with complete evapo-transpiration needs which lead to highest agricultural growth and development, ultimately providing maximum yield. These days, full irrigation system is viewed as an extravagant utilization of water as it has shown insignificant or zero impact on the production of any crop species (Kang and Zhang 2004). Low water consumption irrigation systems are utilized to enhance water productivity (WP). At this time, deficit watering system (DI) and partial root drying watering system (PRD) are the low water consumption strategies that minimizes the water requirements of crops from maximum utilization to very low water needs. Usage of these types of techniques is mostly related to the better growth with no influences on production and ultimately helpful saving extra water (Ahmadi et al. 2010).

Agriculture is the major consumer of available fresh water (Table 1) and it can use a big portion of water than any other user (Huffaker and Hamilton 2007). The world's demand for food is steadily increasing day by day and at the same time, water resources are diminishing. This conflict needs to be resolved. Decidedly, there is a substantial need to increase irrigated areas and crop yield to account for the increasing world population through 2025 (Lascano and Sojka 2007).

\section{Main text}

\section{Partial root-zone drying technique}

Partial root drying (PRD) is the changed type of deficit irrigation system (English et al. 1990). In this method of irrigation, during each irrigation time, we will apply irrigation of only half side of the plant root, and in this way one part of root absorbs water and other remain dry for the next irrigation time. For that reason, the partial root drying technique is an imperative irrigation strategy in that one part of the root is put in dry soil and the remaining part of the
Table 1 Summary of water utilization in agriculture, industry, and municipal sector in different countries of the world

\begin{tabular}{|c|c|c|c|c|}
\hline \multirow{2}{*}{$\begin{array}{l}\text { Serial } \\
\text { no. }\end{array}$} & \multirow[t]{2}{*}{ Country } & \multicolumn{3}{|c|}{ Water use (\%) } \\
\hline & & Agriculture & Industry & Municipal \\
\hline 1 & Australia & 67 & 13 & 20 \\
\hline 2 & Bangladesh & 88 & 2 & 10 \\
\hline 3 & Brazil & 60 & 17 & 23 \\
\hline 4 & Canada & 12 & 73 & 15 \\
\hline 5 & China & 65 & 23 & 12 \\
\hline 6 & Denmark & 25 & 20 & 55 \\
\hline 7 & Egypt & 86 & 3 & 11 \\
\hline 8 & France & 10 & 72 & 18 \\
\hline 10 & India & 91 & 2 & 7 \\
\hline 11 & Iran & 92 & 1 & 7 \\
\hline 12 & Israel & 58 & 6 & 36 \\
\hline 13 & Italy & 33 & 43 & 24 \\
\hline 14 & Japan & 67 & 14 & 19 \\
\hline 15 & New Zealand & 61 & 24 & 15 \\
\hline 16 & Mexico & 77 & 9 & 14 \\
\hline 17 & Pakistan & 94 & 1 & 5 \\
\hline 18 & Philippines & 81 & 11 & 8 \\
\hline 19 & Russia & 22 & 56 & 22 \\
\hline 20 & Spain & 68 & 18 & 14 \\
\hline 21 & South Africa & 60 & 13 & 27 \\
\hline 22 & Turkey & 74 & 11 & 15 \\
\hline 23 & U.S.A. & 36 & 51 & 13 \\
\hline
\end{tabular}

Source: Aqua stat FAO, 2016.

root is grown in irrigated soil conditions (Ahmad et al. 2020; Rashid et al. 2019; Ahmadi et al. 2010). Originally, the PRD concept was primarily used by Grimes et al. (1968) on an experimental cotton trial in the USA by using alternation in furrow irrigation system. This concept was then followed up by Sepaskhah and Sichani (1976), and Samadi and Sepaskhah (1984) on crops (beans) using two trickle irrigation methods known as surface and subsurface. Later on, a lot of studies PRD were carried out in Australia. After those studies, the term PRD was mostly used for grapevine crops (Loveys et al. 2000; Kriedmann and Goodwin 2003). Schematic diagram of FI, DI, and PRD are shown in Fig. 1 (Davies and Hartung 2004).

There are some factors relating to crops such as evaporative demands, growing stage, soil texture, and soil water balances, which affect plants by wetting and drying each side of the roots (Saeed et al. 2008). Farmers have no definitive answer using PRD which will show exactly how much time it should take for each irrigation of either the side of the crop root. Kriedmann and Goodwin (2003) stated that in PRD irrigation, intervals may be changed from irrigated to dry soil when the dry soil root 


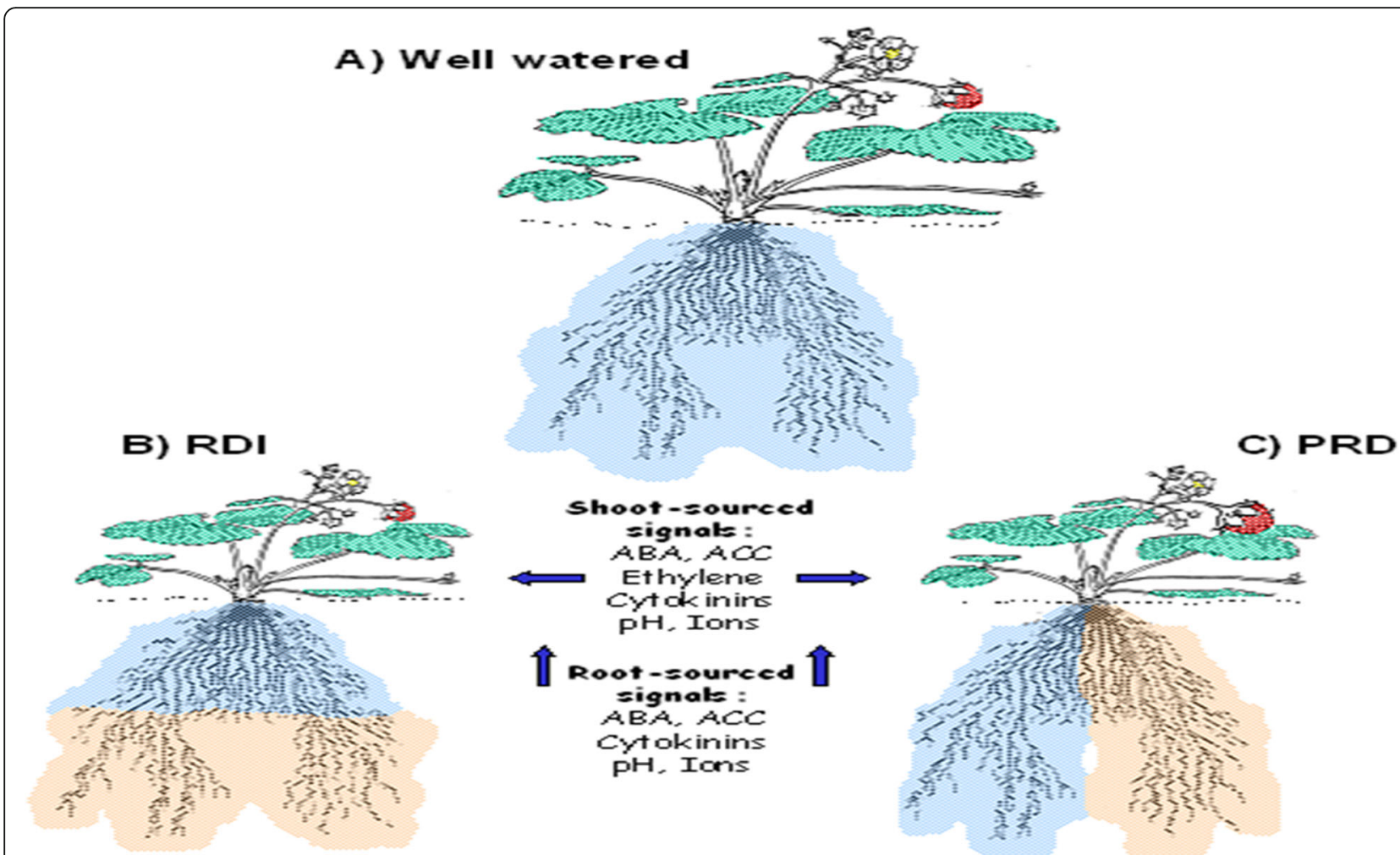

Fig. 1 Schematic diagram of the irrigation pattern in FI (full irrigation), RDI (regulated deficit irrigation), and PRD (partial root-zone drying) (Davies and Hartung 2004)

has zero percent extraction of water from the rhizosphere. Furthermore, Liu et al. (2008) stated that irrigation alteration in PRD must be supported on soil moisture threshold content levels which have the ability to produce the greatest level of abscisic acid (ABA) concentrations of xylem. Roots in drying soils during PRD cause the production of plant hormone ABA which is conveyed due to flowing water in xylem vessels through shoots designed for maintaining shoot functionality (Kang and Zhang 2004). Consequently, by using PRD, plant roots are able to judge the drying soil conditions and stimulate ABA concentrations that causes partial closure of stomatal apertures and reduction in leaf expansion while the roots of the wet portion of soil absorb plenty of soil water to sustain an elevated water condition in the plant shoots (Zegbe et al. 2006; Ahmadi et al. 2010; Liu et al. 2006a; Iqbal et al. 2019 a, b). Different research studies on PRD and DI showed that when we use the same amount of water for these above two irrigation strategies, PRD produced more yield against the DI. This resulted in better fruit quality and higher water productivity (Ahmad et al. 2020; Rashid et al. 2019; Iqbal et al. 2019a; Shahnazari et al. 2007; Leib et al. 2006; Sepaskhah and KamgarHaghighi 1997; Kang and Zhang 2004; Kang et al. 1998; Kriedmann and Goodwin 2003; Kirda et al. 2004; and Liu et al. 2006a). Nevertheless, Wakrim et al. (2005) concluded that there is a similarity between PRD and DI for water use efficiency, but both the strategies have better water use efficiency as compared to full irrigation method (FI). For pot experiments, schematic representation of alternate wettingdrying cycle (PRD) and full irrigation (FI) to plant roots is shown in Fig. 2a, b.

Practical implication of PRD is dependent on many factors such as soil conditions, crop species (cultivars), and condition of the surroundings and the method of irrigation. However, alternating furrow irrigation was considered to be the most beneficial over the other irrigation methods (Grimes et al. 1968). Different crops are grown by using alternate furrow irrigation and PRD which has greater water productivity as compared to alternate furrow irrigation (Musick and Dusek 1982; Kang et al. 2000a; Sepaskhah and Kamgar-Haghighi 1997; Kaman et al. 2006; Sepaskhah and Khajehabdollahi 2005; Samadi and Sepaskhah 1984; Kirda et al. 2005; Sepaskhah and Hosseini 2008; Sepaskhah and Parand 2006; Sepaskhah and Ghasemi 2008). Surface and subsurface drip irrigation methods have shown a greater affect when using PRD on different crop species as in hot pepper crop (Kang et al. 2001), beans crop (Sepaskhah and Sichani 1976), apple fruit (Leib et al. 2006), cotton crop (Du et al. 2008a), potato crop(Ahmadi et al. 2010; Shahnazari et al. 2007; Liu et al. 2006a; Shahnazari et al. 2008), tomato crop (Kaman et al. 2006; Kirda et al. 2004), and grapevine crop (De la Hera et al. 2007; Du et al. 2008b). Low energy 


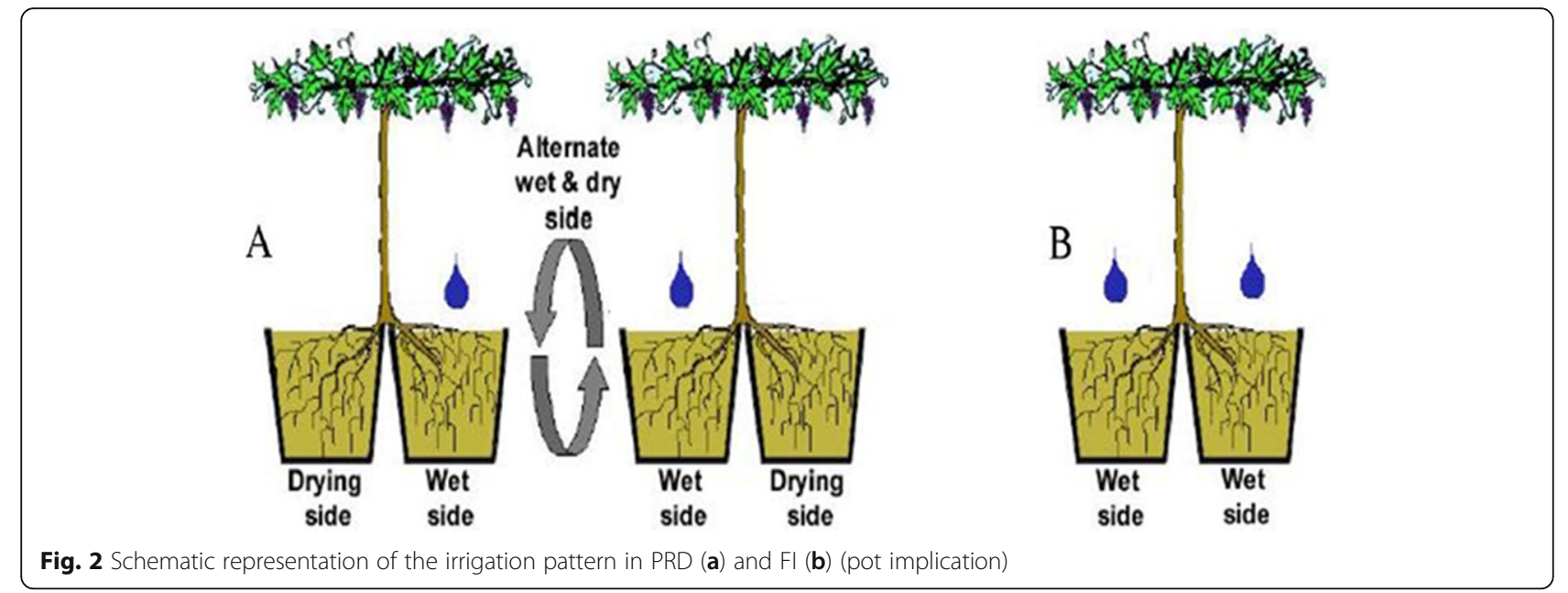

precise application (LEPA) sprinkler method have been successfully used by Schneider and Howell (1999) to apply PRD on maize, winter wheat, and sorghum. For field experiments of PRD, alternate wetting-drying of furrows is carried out in the field with or without drip irrigation system as described in Fig. 3.

\section{Hydraulic signaling and non-hydraulic signaling using PRD technique}

There is an increased production of $\mathrm{ABA}$ during the drying phase of roots as in PRD as compared to normal conditions of soil (Iqbal et al. 2019a; Davies and Zhang 1991), and this ABA concentration is moved in upper parts of plants as an anti-stress chemical signal of roots to limit the stomatal conductance and conserve water in plants which would otherwise transpire through stomatal openings (Iqbal et al. 2019b; Stoll et al. 2000; Bauerle et al. 2006; Kang and Zhang 2004; Liu et al. 2006a; Liu et al. 2005b). There was significant leaf expansion rate in maize due to the usage of PRD (Bahrun et al. 2002), wheat crop (Ali et al. 1999), soybean crop (Liu et al. 2005a), potato crop (Liu et al. 2005c), and tomato crop (Topcu et al. 2007). Reduction of leaf growth and development can impede the utilization of more carbon, energy, and a greater portion of plant photosynthates, which is then circulated to the plant root system to enhance more root expansion which may be helpful in the extraction of water from the soil (Taiz and Zeiger 2006).

Non-hydraulic (chemical) signaling and hydraulic (water) signaling are two types of signaling which are the consequences of wetting and drying cycling of PRD. When there is a slight water stress occurrence, ABA which is a main non-hydraulic signal, works faster in relation to hydraulic signaling. On the other hand, under harsh conditions of water stress, both hydraulic signaling (HS) and non-hydraulic signaling (NHS) simultaneously regulate the normal physiological functions of plants (Liu et al. 2005b; Liu et al. 2003; Ali et al. 1999). It was found that several crop plants, both HS and NHS, function freely but in some plants they work in conjunction. Equilibrium always exists in HS and NHS using PRD (Wakrim et al. 2005; Comstock 2002; Tardieu and Davies 1993).

$A B A$ is a main non-hydraulic signal under the PRD technique. Besides this, other chemical, or non-hydraulic, signals such as concentration of inorganic ions, $\mathrm{pH}$, and other plant hormones (Wilkinson 1999; Stoll et al. 2000).
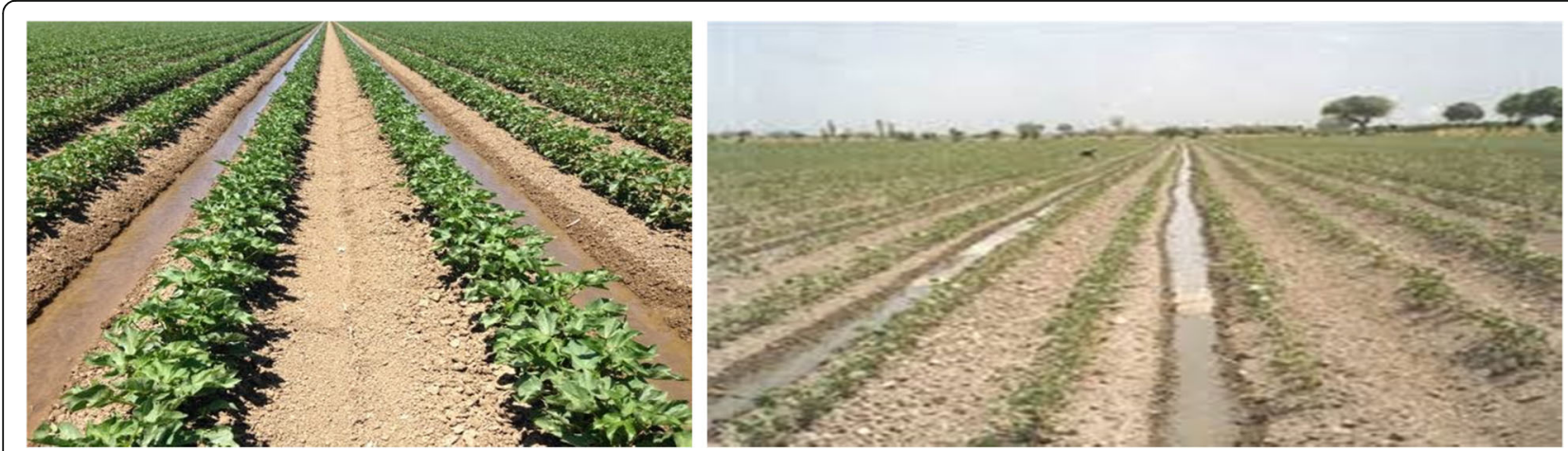

Fig. 3 Schematic representation of the alternate wetting-drying of furrows in field conditions (field implication) 
Occurrence of slight water stress reduces the uptake of essential plant nutrients with the booting of $\mathrm{pH}$ of xylem sap. High concentration levels of ABA in plant leaves move to the stomata via transpirational stream (Taiz and Zeiger 2006; Dodd 2003; Davies et al. 2002; Iqbal et al. 2019a).The mechanism of ABA dependency reduces leaf elongation due to the higher xylem sap $\mathrm{pH}$ (Liu et al. 2003; Iqbal et al. 2019a).

\section{Stomatal conductance and photosynthesis rate using PRD with $\mathrm{CO}_{2}$ exchange}

During the wetting and drying cycle of PRD, the wet side absorbs water to sustain the water status of plants and at the same time the dry side causes a partial closing of the stomata which reduces its transpirational losses through producing ABA. However, a small quantity of water is transpired through the stomatal opening and there is absorption of $\mathrm{CO}_{2}$ which will cause the formation of glucose in the process of photosynthesis. On the other hand, the rate of photosynthesis and stomatal conductance is adversely affected by the changes in stomatal opening and closing. Photosynthetic rate is not affected as much by slight water stress as is leaf expansion (Taiz and Zeiger 2006; Raza et al. 2017). However, stomatal conductance and the photosynthesis rate are severely affected by harsh conditions of water stress on plants.

Intercellular concentration of $\mathrm{Co}_{2}$ which is the main factor in the formation of organic compounds (photosynthesis) is not affected as much as the rate of transpiration by conductance of stomata at the initial stages of water stresses conditions. Both the photosynthesis rate and stomatal conductance have a very low sensitivity to slight water stress conditions but their water productivity increases with low water availability (Liu et al. 2006a; Liu et al. 2005c; Davies et al. 2002). Hydraulic signaling is related to the water potential of leaves. In very harsh water stress conditions, the mesophyll cells of crop plants lose their water potential in such a way that there is a greater inhibition of their photosynthetic rate (Taiz and Zeiger 2006; Raza et al. 2017).

Partial root-zone drying has many advantages in relation to deficit irrigation. Its main benefit is the irrigated side provides water to the plant and, in this way, the water potential remains at such a level that there is no stress to the crop plants. Secondly, the dry portion causes the production of ABA, which in turn, decreases the conductance of stomata (Iqbal et al. 2019a, 2019b; Saeed et al. 2008; Tang et al. 2005; Du et al. 2008b; Costa et al. 2007; Shahnazari et al. 2007) and increases water use efficiency (Davies et al. 2002). Many of the practical studies conducted in different regions show no doubt that stomatal conductance reduces using PRD but the rate of photosynthesis remains the same, as in the case of fully irrigated crop (Raza et al. 2017; Ahmadi 2009; Costa et al. 2007; Ahmadi et al. 2010).

Different scientists have conducted many different experiments using diverse crops in PRD such as Du et al. 2008a, Tang et al. 2005, Du et al. 2006, and Iqbal et al. 2019b (cotton crop experiments); Kang et al. 2001 (hot pepper); Kang et al. 2000a, Kang et al. 2000b, and Du et al. 2010 (maize crop experiments); Du et al. 2008b and De la Hera et al. 2007 (grapes experiments); Liu et al. 2006a, Liu et al. 2008, and Ahmadi et al. 2010 (potato crop); Campos et al. 2009 and Zegbe et al. 2004 (tomato); and Zegbe and Behboudian 2008 conducted experiments on apples and concluded that the photosynthetic rate is not lessened as compared to the crop which is fully irrigated. On the other hand, studies of Liu et al. 2006b (potato) and Kirda et al. 2005 (maize) suggested that by using PRD, there was a significant reduction in the photosynthesis rate. Such disagreements may take place due to the different types of soil found in different regions and that there may be some faults during PRD experimentation (Ahmadi et al. 2010; De la Hera et al. 2007; Costa et al. 2007; Liu et al. 2006a). The two other main factors, selection of variety and agrometeorological conditions, also affect the findings of PRD (Zegbe and Behboudian 2008; Raza et al. 2017).

Rooting system and uptake of water and nutrients in PRD Growth and development of the rooting system, its circulation, and its movement can vary in different soil profiles depending on the moisture and/or water availability (Wang et al. 2006). Foliage and the shoots of crop plants mostly depend on water and nutrient absorption by the roots in the soil. Root expansion and increased root length density become helpful in the uptake of water in the moist area of PRD through the vigorous growth of roots (Songsri et al. 2008; Benjamin and Nielsen 2006). Previous studies showed that PRD improved the expansion of plant roots and caused the mortification of primary and secondary roots in plants (Kang et al. 2000b), a greater enhancement in root growth and development of crops (Dry et al. 2000) and their root biomass (Kang et al. 2000a; Mingo et al. 2004), an improved hydraulic conductivity due to ABA concentrations (Thompson et al. 2007; Taiz and Zeiger 2006; Glinka 1980), and more enhanced absorption of essential plant nutrients (Wang et al. 2009). Dry soil in PRD shows a greater absorption of water due to greater hydraulic conductivity after a low soil water stress condition (Kang and Zhang 2004).

In the wet-dry cycling of PRD, this recompense of hydraulic activity is due to the formation of secondary plant roots and already existing old shoots during wetting phase (Kang and Zhang 2004). Poni et al. (1992) conducted experiments on apple, grape, and peach trees in low water conditions and concluded that hydraulic 
conductivity of these increased in restricted irrigation. Other studies also proved that uptake of plant nutrients is at its maximum in partial root drying (PRD) than full irrigation (FI) for diverse arable crops (Shahnazari et al. 2008; Kirda et al. 2005; Li et al. 2007; Wang et al. 2009). The phenomenon behind this is the formation of new roots during PRD resulting in elevated nutrient being absorbed from the soil caused by the supplementary availability of soil water given to the roots (Kang and Zhang 2004).

The irrigated side of PRD used water more effectively as compared to same amount of water in the fully irrigated plant (Rodrigues et al. 2008; Kang et al. 2003; Kang et al. 2000b). This irrigated side can compensate for water requirements of the non-irrigated or dry portion of the root-zone due to hydraulic conductivity of the plant root system in relation to a well-watered crop plant (Liu et al. 2006a). This is because of the enhanced capability of roots in PRD as compared to any other irrigation method. PRD also has an advantage over deficit irrigation (roots have to face much of the time to dry soil conditions) as the plant roots have undergone many physiological and anatomical changes and ultimately there is loss of many of the root cells (North and Nobel 1991).

\section{Mechanism of increasing water productivity in PRD}

Most people consider both the terms of water use efficiency (WUE) and water productivity (WP) as the same but there is a difference in both the terminologies, wherein water use efficiency is defined as the crop yield per unit of evapotranspiration; and water productivity is the crop yield per unit of irrigation water applied or the "crop per drop" (Zhang 2003). Dry portion of PRD produces ABA which causes the reduction in stomatal closure or partially opening of stomata and reduction in the formation of foliage in plants; these are the main reasons of controlling the transpirational losses in plants under PRD and enhancing the overall yield (Table 2) and quality of crops (Davies et al. 2002). Stomatal conductance has a negligible impact on the rate of photosynthesis. It is obvious from the above facts that stomatal conductance has a great influence in controlling the transpiration rate with limited effect on photosynthesis (Morison et al. 2008).

According to Ahmad et al. (2020), Rashid et al. (2019), Ahmadi et al. (2010), Sepaskhah and Kamgar-Haghighi (1997), Geerts and Raes (2009), Davies et al. (2002), Zegbe et al. (2004), Sepaskhah and Khajehabdollahi (2005), Shahnazari et al. (2007), Shani-Dashtgol et al. (2006), Costa et al. (2007), and Fereres and Soriano (2007), water productivity of various crop species mainly increased during PRD application (Table 2). Sadras (2009) concluded in an economic analysis that there is $82 \%$ increase in the water productivity using PRD in relation to the fully irrigated plants. On the other hand, some scientists disagree with this in some crop's water productivity. PRD was less efficient than DI in increasing water productivity (Liu et al. 2006b). According to Wakrim et al. (2005) and Kirda et al. (2005), deficit irrigation has more water productivity (Ezzo et al. 2020) in melon as compared to FI. However, fruit quality was greater in PRD as contrasted to the deficit method of irrigation (Shahnazari et al. 2007; Kang and Zhang 2004; Zegbe et al. 2004; Kirda et al. 2004; Leib et al. 2006). De la Hera et al. (2007) and Ahmadi et al. (2010) gave some points to investigate the differences in effectiveness of PRD in relation to DI such as (a) which hormones are involved during the reproductive stages of crops in

Table 2 Comparison of yield and water use efficiency under control and PRD irrigation in different crops

\begin{tabular}{|c|c|c|c|c|c|c|c|}
\hline \multirow{2}{*}{$\begin{array}{l}\text { Sr. } \\
\text { No. }\end{array}$} & \multirow{2}{*}{$\begin{array}{l}\text { Experiment } \\
\text { location }\end{array}$} & \multirow[t]{2}{*}{ Crop } & \multicolumn{2}{|l|}{ Yield } & \multicolumn{2}{|c|}{ Water use efficiency } & \multirow[t]{2}{*}{ References } \\
\hline & & & Control & PRD & Control & PRD & \\
\hline 1 & Australia & Grapes & 3.94 & 3.69 & 7.4 & 13.9 & Du Toit et al. (2003) \\
\hline 2 & Serbia & Potato & 53.19 & 50.46 & 236.40 & 380.14 & Stikic et al. (2014) \\
\hline 3 & New Zealand & Tomato & 52.4 & 49.8 & 1.2 & 2.2 & Zegbe et al. (2007) \\
\hline 4 & Malaysia & Tomato & 8.52 & 7.44 & 1.56 & 2.39 & Ali et al. (2004) \\
\hline 5 & Serbia & Tomato & 10.73 & 10.05 & 0.21 & 0.34 & Stikic et al. (2003) \\
\hline 6 & Syria & Maize & 8.5 & 6.1 & 12.80 & 16.20 & Alkhaldi et al. (2012) \\
\hline 7 & Egypt & Sugarcane & 63.50 & 57.33 & 12.1 & 16.1 & Ibrahim and Emara (2010) \\
\hline 8 & Iran & Canola & 1.81 & 1.63 & 0.37 & 0.67 & Mousavi-Avval et al. (2011) \\
\hline 9 & Peru & Potato & 45.1 & 36.2 & 4.9 & 8.1 & Posadas et al. (2008) \\
\hline 10 & Egypt & Tomato & 11.00 & 9.00 & 26 & 43 & Affi et al. (2012) \\
\hline 11 & New Zealand & Pepper & 3.70 & 3.45 & 1.20 & 2.00 & Dorji et al. (2005) \\
\hline 12 & Turkey & Maize & 10.00 & 6.97 & 1.61 & 2.09 & Yazar et al. (2009) \\
\hline 13 & China & Cotton & 5.8 & 5.4 & - & - & Tang et al. (2005) \\
\hline 14 & Pakistan & Wheat & 5.52 & 4.75 & 1.89 & 2.67 & Ahmad et al. (2020) \\
\hline
\end{tabular}


PRD, (b) rooting system of crops in PRD and water and nutrients uptake system, (c) difference in chemical signaling, and (d) consider the scheduling of PRD as compared to DI and quantity of water applied.

Ahmadi (2009) and Dodd (2009) reported significant effects with the application of PRD on different annual crops and tree species with greenhouse and field studies. They reported significant water saving and more economic yield in their studies with PRD. Approximately, $30-50 \%$ of irrigation water may be conserved with PRD in different experimental results with no or very low yield reduction. In some research studies, there was even better fruit quality due to partial root drying (PRD) (Du et al. 2008b; Guang-Cheng et al. 2008; Kirda et al. 2004; Leib et al. 2006; Kang and Zhang 2004; Shahnazari et al. 2007; $\mathrm{Du}$ et al. 2008a). PRD work is still ongoing from the last decade in reference to different horticultural and agronomical crops (Iqbal et al. 2019a, 2019b; Ahmad et al. 2020; Rashid et al. 2019), along with the development of some other irrigation techniques and methods (Ahmadi 2009; Morison et al. 2008; Guang-Cheng et al. 2008).

\section{Agricultural advantages of $A B A$ in PRD}

In the last few decades, a large number of field studies on PRD are still ongoing and have proved the benefits of chemical signaling of ABA induced in PRD in areas of low water availability. The first who applied the half-way root irrigation techniques were Loveys et al. (2000) where they conducted a field experiment on grapes and concluded its positive effects on the grapevine. There was reduced action foliage growth which avoided tranpirational losses and simultaneously improved the quality of fruit and produced high yield with low water. Some other field experiments of PRD also conducted in Australia on grapevine proved that in addition to the above mentioned benefits of PRD, it can also increase water productivity or water use efficiency of many crops (Loveys et al. 2000).

\section{Effects of PRD on agronomic, horticultural, and tree species \\ Agronomic crops \\ Sugarcane and sugar beet}

Sepaskhah and Kheradnam (1977) conducted a field experiment on sugar beet crops using the alternate furrow irrigation system and concluded that there was only a reduction of $18 \%$ in the sugar beet yield with the 10-day interval of alteration of water supplying. The sugar beet consumed $34 \%$ less water as compared to the fully irrigated crop plants. So, the sugar beet conserved water using the PRD system, because alternation irrigation method is a PRD technique. De la Hera et al. (2007) concluded that PRD should be scheduled according to the soil conditions (texture and structure), climatic factors, and cultivars grown. As in the case of the sugar beet being a short duration vegetative crop, short intervals of irrigation may be beneficial for yield enhancement and water conservation.

Sepaskhah and Kamgar-Haghighi (1997) examined the impacts of each furrow watering system on sugar beet crop for its production and water productivity at various irrigation system interims of (a) 6 days, (b) 10 days, and (c) 14 days. Findings of their research showed that each furrow irrigation system having 10-day irrigation gap consumed very low water quantity for irrigation purpose. In any case, there was a slight reduction in the root biomass. Then again, every alternated furrow irrigation system having 6-day interims lessened $23 \%$ irrigation water when contrasted to each furrow watering system having 10-day period. Comparative results were additionally acquired for sugarcane having the inconsistent alternate furrow irrigation, as in PRD, was utilized to decide the impacts of PRD on sugarcane in hot and dry Iranian regions (Shani-Dashtgol et al. 2006).

Outcomes of the study showed, by using the alternated furrow watering system, that there was a $26 \%$ reduction of the applied irrigation water as compared to the full watering method producing a $10 \%$ yield increase of sugarcane. When there was a comparison of water productivity, PRD increased the WP of about $34 \%$ in relation to the fully irrigated system. Equal water productivity was also reported for sugar beet crops by Sepaskhah and Kamgar-Haghighi (1997). In India, a field experiment of sugar cane crop was conducted by Pandias et al. (1992) and reported that 43 to $46 \%$ low water utilization in PRD for sugarcane crop which is much higher than suggested by Shani-Dashtgol et al. (2006).

\section{Sorghum}

Sepaskhah and Ghasemi (2008) carried out an experiment on sorghum crop in a hot and dry area of Iran with different intervals of irrigation as (a) 10 days, (b) 15 days, and (c) 20 days. There was a slight reduction in yield of about $28 \%$ with increased water productivity of the intervals of 15 days. They concluded that the interval of 10 days is most effective because there is no yield reduction but increased water productivity around $11 \%$ as compared to fully irrigated sorghum crop in alternating furrow irrigation system.

\section{Wheat}

Sepaskhah and Hosseini (2008) investigated the response of wheat to PRD supplementary irrigation system which is cultivated in rain-fed conditions (less than $250 \mathrm{~mm}$ rainfall annually) and they concluded that this supplementary irrigation in rain-fed areas is additionally successful in enhancing the production of wheat crop. They used alternated furrow irrigation system in comparison with the conventional furrow irrigation method in a region having an annual rainfall of about $409 \mathrm{~mm}$. Grain 
yield obtained in alternate irrigation system was the same as in conventional system of irrigation (just about $15 \%$ reduction) and the water usage of this alternate system was approximately $41 \%$ less in relation to convention irrigation method.

Raza et al. (2017) carried out a pot experiment in nethouse to evaluate the impacts of partial rhizosphere drying (PRD) and control (FI) irrigation on five different wheat genotypes. Findings of that research study showed that higher values of growth, water-related parameters, and physiological attributes were obtained under control treatment except total proline, total sugar content, leaf water, and osmotic potential which were sufficiently higher in PRD applied treatments due to more ABA production. All five wheat varieties showed greater enzyme activities in PRD in relation to control treatment.

Iqbal et al. (2019a) concluded that PRD is uncommonly magnificent water system technique to conserve the water needed by plants and boosting the leaf water use efficiency (WUE). Higher development, physiological, and yieldrelated parameters of wheat were seen in full water system applied treatment in correlation of PRD and DI. More ABA and osmotic modification was found in PRD-treated plants than other water systems. Leaf WUE was likewise higher in PRD plants in examination of FI and DI. PRD is the most productive water system technique than DI in water-constrained territories world widely.

Ahmad et al. (2020) found that wheat yield properties were more in control/normal water system treatment while grain nitrogen, phosphorus, potassium (NPK) substance and water use efficiency were more in PRD treatment. All ground covers uniquely improved the wheat yield properties and quality substance just as proficiently controlled the weeds when contrasted with open (reveal) ground conditions. Joined utilization of PRD with black plastic spread mulch gave best results than different mulches utilized in the trial.

\section{Maize}

Sepaskhah and Khajehabdollahi (2005) conducted a PRD (alternating furrow irrigation system) experiment on maize crop, which is a very sensitive crop for moisture. Different intervals of irrigations were kept such as (a) 4-day interval, (b) 7-day intervals, and (c) 10-day intervals. With the use of 7-day interval on maize crop, they concluded that about $28 \%$ lessened of grain yield occurred with $31 \%$ low consumption of applied irrigation water. On the other hand, use of 4-day interval showed that there was no reduction of grain yield but reduced the applied water of about $6 \%$ as compared to 7-day irrigation interval.

Sepaskhah and Parand (2006) observed that PRD was less effective in hot and dry areas of the world for grain crops. So, they decided to use PRD in a furrow system but at the susceptible phonological stage of maize (silking and tesseling) crop, there would be added an extra irrigation to avoid the reduction in grain yield. They compared the PRD (alternated furrows irrigation system) with the furrow irrigation system giving an extra irrigation at critical growth stages of maize and concluded that the grain production was almost the same (reduction of 11\%) but there was an increased WP of about $30 \%$.

Kang et al. (2000a, 2000b) used different alternating irrigation water strategies in a hot and dry region of China in an irrigated maize crop. Two factors were used to study the PRD. One was the different furrow irrigation such as (a) alternate furrow irrigation, (b) fixed furrow irrigation, and (c) conventional furrow irrigation. The second factor was the different levels of irrigation. These irrigation levels are as follows: (i) $45 \mathrm{~mm}$, (ii) $30 \mathrm{~mm}$, and (c) $22.5 \mathrm{~mm}$. Moreover, they reported that alternate furrow irrigation (PRD) resulted in higher increase of grain yield of maize crop with consumption of $50 \%$ less irrigated water as compared to fixed and conventional irrigation method. Both the fixed and conventional furrow irrigation systems had reduction in grain yield with limited amount of water in relation to alternate furrow method (PRD).

\section{Beans}

Samadi and Sepaskhah (1984) carried out an experiment on dry beans crop in a dry and hot region to check the effectiveness of PRD using alternate furrow irrigation system. Using alternate furrow irrigation technique, there was reduction of $38 \%$ grain production of dry beans with a $22 \%$ decrease in the irrigation water. They found that in alternate furrow system, there was the most reduction of yield. So, to compensate for this yield gap, they used supplemental irrigation with the alternate furrow irrigation system at a critical growth stage (podding) of dry beans and concluded that the dry beans yield is statistically significant (reduction of about 9\% yield) in relation to furrow irrigation system with $29 \%$ less water consumption.

Wakrim et al. (2005) conducted a research study of beans in pots to evaluate the effects growth and water relation parameters of partial root drying, deficit irrigation, and fully irrigated crop plants. The water potential of lea was higher in fully irrigated crop than the PRD and DI, but the values of leaf water potential showed no main difference by using PRD and DI. Moreover, the biomass of shoot and pod was statistically higher in FI than both the PRD and DI. These outcomes of the research study are similar with the findings of Samadi and Sepaskhah (1984).

Gencoglan et al. (2006) investigated the effects of subsurface drip irrigation of both the conventional and alternate system to study water use efficiency and yield of green beans. Both the subsurface conventional (CSDI) and alternated (ASDI) drip irrigation are the parts of PRD (partial root drying). Production of green beans 
was the same for both the CSDI and ASDI but there was conservation of $50 \%$ water in ASDI in relation to CSDI.

\section{Cotton}

DuT et al. (2006) conducted a research study on cotton crop to evaluate the impacts of PRD on cotton production and its physiological related parameters. Three different methods of irrigation were carried out named as (a) fixed PRD furrows irrigation system (FFIS), (b) alternated PRD furrows irrigation system (AFIS), and (c) conventional furrows irrigation system (CFIS). Three irrigation levels were used such as (i) $22.5 \mathrm{~mm}$, (ii) $30 \mathrm{~mm}$, and (iii) $45 \mathrm{~mm}$ for every cycling of PRD. The findings of the study revealed that AFIS has the maximum yield of seed cotton and water use efficiency and reduction of water losses occurred in PRD using AFIS.

Du et al. (2008a) contrasted PRD and full irrigation system (FI) for the cotton crop by use of drip irrigation system with three different levels of irrigation. These levels were considered as (a) $15 \mathrm{~mm}$, (b) $22.5 \mathrm{~mm}$, and (c) $30 \mathrm{~mm}$ and comparable results were achieved by DuT et al. (2006). They demonstrated that comparative seed cotton production was acquired with PRD and FI irrigation systems. Further, 31 to $33 \%$ reduced irrigation water in PRD system in relation to FI irrigation system. However, comparative results from an analysis utilizing the alternate furrow watering system (PRD) and conventional furrow watering system (FI) were likewise suggested through Tang et al. (2005). They concluded that using PRD technique reduced watering system by $30 \%$; at the same time, its economic yield was lessened by $8 \%$ which was not statistically significant in relation to FI.

Iqbal et al. (2019b) concluded that a superior development and a higher photosynthesis rate in cotton were seen under full water system (FI) than under PRD water system; be that as it may, the proline and all other sugar substance, and concentrations of antioxidants were fundamentally higher in cotton plants under PRD water system than under full water system. Then again, mulching affected soil moisture (Kader et al. 2019; Iqbal et al. 2020) and henceforth essentially improved the proficiency of PRD water system. Among mulching applications, $\mathrm{M}_{2}$ performed the best under PRD water system. In this way, joined utilization of PRD water system and $M_{2}$ in the field merits further regard for streamline cotton production with less water in arid regions.

\section{Horticultural crops \\ Potato}

Liu et al. (2006a) conducted greenhouse as well as a field experiment to check the effects of PRD on growth and development of potato crop. Two treatments were used in both greenhouse and field experiment one being the PRD and second were the FI (fully irrigated). Used; one being the drip irrigated alternate furrow and one being the fully irrigated. In the field experiment, PRD got maximum water use efficiency as compared to FI. PRD-treated plots lessened the water usage of about $30 \%$ with no reduction in production of tuber and gained 60\% water use efficiency.

Liu et al. (2006b) conducted another experiment to study the effects of different irrigation techniques on tuber initiation stage of potato crop. Three irrigation methods were used: PRD, DI, and FI. Outcomes of the research study showed that PRD and DI significantly reduced potato tuber production in relation to the fully irrigated crop and these findings disagree with their earlier results (Liu et al. 2006a). In addition, both the PRD and DI consumed 37\% lower amount of water as compared to FI but the water use efficiency was reduced in DI in relation to both of PRD and FI. The water use efficiency was the same for PRD and FI but PRD showed no additional benefit using the same amount of water in regards to water use efficiency than DI. The main reason behind this is the low water application in PRD which resulted in severe water stress. Some other studies also forced the idea that some unidentified factors should be recognized while studying the PRD and DI that effect the water relations of soil and plant (Wakrim et al. 2005; Gencoglan et al. 2006; Costa et al. 2007).

Shahnazari et al. (2007) carried out a research study in open field designed for a long time to examine the impacts of FI system and PRD technique, with the use of 70\% water of FI on potato production, tuber size, and water profitability of potato. Consequence showed that no critical distinction in leaf area index happened. However, biological and economical yield was somewhat lesser in PRD in relation to FI. The profitable tuber production (size of 40 to $50 \mathrm{~mm}$ ) was $20 \%$ elevated in PRD as compared to FI. At last, PRD conserved $30 \%$ of irrigation water and brought about $61 \%$ increase in irrigation water profitability combined with keeping up tuber yield and more attractive tuber size. Comparable results on potato were additionally reported by Jovanovic et al. (2010).

Ahmadi et al. (2010) found that there is a sound relationship between the PRD effects and characteristics of soil profile. Soil has many influences on the water usage ability of crop plants and water retention capacity which differs with the texture of soil from region to region. By the usage of coarse sand, there was an increase of $11 \%$ in water productivity and $36 \%$ water productivity was achieved with sandy loam soil as compared to fully irrigated crops in above both type of soils. However, water productivity was lessened by $15 \%$ by using loamy sand. There is a need that before the conduction of PRD experiments, we should know the soil features, cultivar characteristics, and climatic factors of the area.

\section{Tomato}

Kirda et al. (2004) carried out PRD experiments using greenhouse for tomato crops and estimated that PRD 
lessened about half of the irrigation water requirement by crop with a slight decline in productivity. They demonstrated that in PRD technique, there was a slight reduction in leaf area index and vegetative growth; in this way, end product of photosynthesis relocated to fruit growth and development. Zegbe et al. (2004) directed a comparable study on processing greenhouse tomato utilizing full irrigation system (FI) and half of FI water saved as PRD. They demonstrated that the fruit and economic production was the equivalent for the different treatments; however, water use efficiency for the plants in PRD were 70\% higher than that acquired in FI plots.

Zegbe et al. (2006) conducted an experiment on different growth stages of tomato to compare the effects of PRD and FI on the production, water use efficiency and quality of tomato crop. Different growth stages of tomato were used as follows: (a) flowering, (b) fruit setting, and (c) maturity. Water was conserved in different growth stages of tomato as in flowering stage (6\%), fruit setting (20\%), and at maturity/harvesting (25\%) than the FI but there was no significant difference for water productivity at different growth stages of tomato. The fresh weight of tomato fruit was reduced at all growth stages, but this fresh weight was compensated by the tomato fruit quality being enhanced in comparison to the FI tomato. These findings emphasize that reproductive crops, such as tomato, have considerations that should be made to achieve better quality and production when applying PRD according to the site specifications and in the scheduling of PRD.

\section{Hot pepper}

Kang et al. (2001) conducted an experiment of PRD in a drip watering system framework for hot pepper crop using pots as alternate trickle watering system (ADI), fixed trickle watering system (FDI), and even drip watering system (EDI). They demonstrated that ADI brought about no decrease in economical production but there was a greater decline in applied water of irrigation about $40 \%$ contrasted with EDI. Guang-Cheng et al. (2008) demonstrated in another greenhouse study that PRD essentially decreased yield about $24 \%$, while water efficiency was enhanced in a result of 52\% compared to FI; however, the fruit yield and its quality was improved. Considering all the above factors, PRD improved the yield with $17 \%$ in relation to DI.

\section{Tree species}

Pear

Fixed partial root-zone irrigation system (FPRD) was compared with partial root drying technique and entire root-zone watering system (WRI) in a pear plantation in Australia utilizing a surge watering system framework (Kang et al. 2002). The outcomes demonstrated that yield was not lessened while the applied watering system's water was reduced about $52 \%$ and $23 \%$ and water use proficiency was improved $28 \%$ and $12 \%$ in FPRD and PRD, separately, in relation to WRI.

\section{Apple}

A research study was directed by small-scale sprinkler to examine the impacts of deficit irrigation and partial root drying on apple yield and its fruit quality for a period of 3 years in America (Leib et al. 2006). Using control irrigation system $(\mathrm{CI})$, water content of the soil was reserved beyond $80 \%$ of field limit; during the first 2 years experimentation, this field limit was about $50 \%$ and in studies last year, it was about $60 \%$ of control for DI and PRD. Findings of research showed no statistically significant distinction in apple production and agricultural fruit size among different comparable treatments for the earliest and final time of research study; in any case, in the second year, just DI demonstrated a fundamental decrease in production than that of control irrigation system. After much study, Zegbe and Behboudian (2008) concluded that PRD could not antagonistically influence the economic production and quality of apples and enhanced water productivity by $120 \%$, with saving of 0.14 mega liters of water in 1 ha.

\section{Olive}

The main assessment of olive tree species using PRD was made by Wahbi et al. (2005); they demonstrated that with the application of PRD, it may be possible to keep up the yield and end product quality, despite the fact that diminishing portion of the irrigation system water. They demonstrated that PRD slightly affected the yield lessening (15-20\%) in relation to the complete irrigation method and it was accomplished with half of decline in the aggregate sum of applied water, which brought about a water use productivity increment about 60 to $70 \%$ under PRD contrasted with the FI.

Fernandez et al. (2006) carried out a field experiment on olives to evaluate the main difference on physiology of olives by applying the partial root-zone drying and deficit irrigation system. They concluded that there was no significant difference on different physiological parameters of olives by using PRD in comparison of DI. There was neither effect on growth, development nor on yield-related parameters of mature olive trees. They also suggested that the application of PRD is costly and hard to run and had no significant agronomic benefits of PRD in relation to FI.

\section{Grape}

The majority of studies of PRD on wooded crop plants were made on grapes that come into view to react well to this sort of low watering system methodology (Fernandez et al. 2006). There are more research studies on grapes and abundant information on the effective use of PRD but limited studies on grapes crop in regards to 
increasing water productivity and fruit quality (Kang and Zhang 2004; Sadras 2009).

De la Hera et al. (2007) conducted a complete PRD research study of 3 years on grapes in Spain in hot and dry conditions. Parameters of water relations of leaf, development of vegetative growth, and fruit quality and production were taken. Partial root drying and conventional irrigation methods were utilized for irrigation with about 30 percent of crop total evapotranspiration. During the first 2 years, results showed that there were no statistically significant outcomes of PRD about transpirational and assimilation growth rates. Besides this, the effect of PRD on vegetative growth and development, grape production, and quality of fruit was not observed. Vegetative growth and fruit production improved in the final year of research study by using PRD in relation to CI. PRD achieved higher yield production (43\% more) and improved ( $40 \%$ more) water use efficiency over CI. Moreover, wetting-drying cycle should be scheduled in order to achieve elevated results of PRD in water deficit areas.

\section{Advantages and disadvantages of PRD}

PRD irrigation has its advantages in regards to water productivity, water use efficiency, fruit quality of most of the crop plants, and nutrient uptake in plants, but it is imperative to evaluate how large of an extent PRD can conserve water in a growing period. The concern for a more economical and efficient use of water has already shown that a positive impact can be made as the majority of PRD treatments use less water (typically $50 \%$ less) than control treatments plants. Besides its water saving efficiency, PRD is suggested to also have positive effects on nutrient uptake in plants and best fruit quality with very low, or negligible, losses in crop yield (Dos Santos et al. 2003).

\section{Advantages of PRD}

\section{Water usage and water use efficiency}

Water use efficiency of fully irrigated (FI) treatments is reduced as compared to water use efficiency of PRD (Ahmad et al. 2020; Rashid et al. 2019; Ezzo et al. 2020) as suggested in several crop species such as cotton crop, tomato crop, pear tree, grapevine orchard, wheat, and hot pepper crop. In maize crop, PRD irrigation technique reduced water usage by $35 \%$ with a biomass decline of about $6-11 \%$ in relation to fully irrigated crop plants (Kang and Zhang 2004). In another research study of hot peppers crops using drip irrigation technology, it reported that PRD reduced water consumption in irrigation by $40 \%$ and lent the same production as in fully irrigated crop plants (Kang et al. 2001). PRD drip technology was used in different areas of the world like China, Yangling and Shaanxi in orchards of peach and apple (Gong et al. 2001), with flood irrigation system in pear orchard in Victoria and Australia (Kang et al. 2002). Conclusions reported water reduction of $52 \%$ in peach orchard and $23 \%$ in pear orchard correspondingly (Kang and Zhang 2004).

\section{Fruit quality of crops treated PRD}

PRD strategy can achieve better quality fruit in many different species such as grapes (Dry et al. 2000), cotton crop (Tang et al. 2005; Iqbal et al. 2019b), cantaloupe (Ezzo et al. 2020), wheat (Ahmad et al. 2020; Rashid et al. 2019), tomato crop (Kirda et al. 2004), and hot pepper (Dorji et al. 2005) crop in many areas of the world. In grape orchards, the sugar substance of grapes was enhanced with the proper application of the PRD technique (Stoll et al. 2000; Dos Santos et al. 2003). They have concluded that this is mainly an effect of improved management of PRD and vegetative growth with the development of the grapevine species. Furthermore, Dry et al. (2000) established that wine quality was consistently better from PRD vineyards.

\section{Nutrient and water uptake in PRD}

An additional advantage from PRD-forced new roots may perhaps be associated to their role in uptake of soil moisture essential plant nutrients/elements. The dryingwetting sequence is a result of PRD forced roots and this can provide the essential elements in soil profile more accessible to the crop plants under PRD (Kang et al. 2001; Dos Santos et al. 2003).

Sugar, proline, and antioxidants (plant defense mechanism) Antioxidant enzymes like SOD, POD, CAT, and APX act as a defense mechanism to engulf the reactive oxygen species (Sadak et al. 2019; Sadak et al. 2020) which are produced as a result of abiotic stress conditions. Besides this, total sugar and proline contents were also higher under PRD irrigation system than the control irrigation (Abdallah et al. 2019; Iqbal et al. 2019b; Raza et al. 2017). These are powerful weapons for plant defense mechanism against adverse climatic conditions (Abdallah et al. 2019).

\section{Disadvantage of PRD}

Production of ABA during PRD results in the partial closure of stomata for the reduction of transpirational losses but at the same time there is reduction in the $\mathrm{Co}_{2}$ uptake by the plants. Reduced $\mathrm{Co}_{2}$ causes decrease in biomass production in plants undergoing PRD. In fruit trees, there was no observation recorded of yield reduction but in cereals there is about $10 \%$ low yield recorded due to less absorbance of $\mathrm{Co}_{2}$ (Shahnazari et al. 2007). Proper scheduling is necessary to run PRD technique; otherwise, there may be problem in salinity during the dry phase of PRD if period exceeds than the normal timing of experiment. 


\section{Future needs}

1. Water requirement of crops vary from climate to climate and taking into account their sensitivity to water (drought sensitive and tolerant crops). So, it is necessary to estimate how much water should be used as PRD, i.e., $\mathrm{PRD}_{100}, \mathrm{PRD}_{70}, \mathrm{PRD}_{50}$ in different crops under different climatic conditions.

2. New roots when exposed to dry periods for a long time may lose their sensibility and contact with soil. It is necessary to know how long these roots can survive under PRD and what effects will be brought on if the wetting and drying cycle is shifted more or less frequently.

3. Some growth stages of crops are critical for water. So, there is also a need to investigate at which growth stages should PRD be applied or avoided.

4. Crop coefficients under PRD should be evaluated so that they can be applied in irrigation water management.

5. Experiments should be conducted to study the efficiency of PRD under different types of soils.

6. Fertilizer application methods and doses under PRD should be evaluated in order to enhance the efficiency of PRD.

\section{Conclusion}

PRD irrigation technique is an imperative strategy of water conservation and, from the last decade, is mostly adopted for horticultural, agronomical, and tree species to increase water productivity in crop plants in water scarce areas. PRD is a more efficient method than the deficit irrigation method and can save agricultural water about $50 \%$ without causing reduction in production and improve the fruit quality in comparison of conventional and deficit irrigation technologies of irrigation. Some of the factors which effect the better results of PRD are crop/cultivar grown, environmental factors, and edaphic factors. Some reproductive crops may be very sensitive to limited water as in PRD, so for such crops, one or two extra irrigations should be carried out at critical growth stages. Nowadays, there is a shortage of fresh water for agricultural production of crops. There is no doubt that PRD is a novel irrigation technique but it is recommenced that usage of mulches (Black plastic, wheat straw, and cotton sticks mulch) would be additionally beneficial to PRD (Iqbal et al. 2019b; Ahmad et al. 2020) while still providing a reduction of water losses, an increase in water use efficiency, an improvement in water productivity and better fruit quality.

\section{Abbreviations}

PRD: Partial root-zone drying; DI: Deficit irrigation; RDI: Regulated deficit irrigation; Fl: Full irrigation; ABA: Abscisic acid; WUE: Water use efficiency; WP: Water productivity; LEPA: Low energy precise application; HS: Hydraulic signaling; NHS: Non-hydraulic signaling; NPK: Nitrogen, phosphorus, potassium; CSDI: Conventional subsurface drip irrigation; ASDI: Alternate subsurface drip irrigation; FFIS: Fixed furrows irrigation system; AFIS: Alternate furrows irrigation system; ADI: Alternate drip irrigation; FDI: Fixed drip irrigation; EDI: Even drip irrigation; Cl: Control irrigation; FPRD: Fixed partial root-zone drying; WRI: Entire root-zone irrigation; SOD: Superoxide dismutase; POD: Peroxidase; CAT: Catalase; APX: Ascorbate peroxidase; $\mathrm{CO}_{2}$ : Carbon dioxide

\section{Acknowledgements}

The authors thank the anonymous reviewers for providing constructive comments and suggestions.

\section{Authors' contributions}

$\mathrm{RI}, \mathrm{MASR}, \mathrm{MA1}$, and FH contributed to the conceptualization and analysis, and wrote the paper. MT, MHR, MSZ, and SA reviewed, edited; UR, MA2, $M U A$, and $I H$ proofread the paper. All authors read and approved the final manuscript.

Funding

This research has not received any funding.

Availability of data and materials

All data generated or analyzed during this study are included in this published article.

Ethics approval and consent to participate Not applicable.

\section{Consent for publication}

Not applicable.

\section{Competing interests}

The authors declare that they have no competing interests.

\section{Author details}

${ }^{1}$ Department of Agronomy, University College of Agriculture \& Environmental Sciences, The Islamia University of Bahawalpur, Bahawalpur, Pakistan. ${ }^{2}$ Lithuanian Center for Agriculture and Forestry (LAMMC), Vainotiškiai, Lithuania. ${ }^{3}$ Department of Agro-ecology, Agricultural Systems and Sustainability, Aarhus University Denmark, Blichers Alle 20, 8830 Tjele, Denmark. ${ }^{4}$ Institute of Crop Science and Resource Conservation (INRES) Crop Science Group, University Bonn, Bonn, Germany. ${ }^{5}$ Department of Agronomy, Muhammad Nawaz Shareef University of Agriculture, Multan, Pakistan. ${ }^{6}$ Soil and water Testing Laboratory for Research, Agriculture Department, Government of the Punjab, Bahawalpur 6300, Pakistan. ${ }^{7}$ Department of Soil Science, University College of Agriculture \& Environmental Sciences, The Islamia University of Bahawalpur, Bahawalpur, Pakistan.

Received: 30 April 2020 Accepted: 30 August 2020

Published online: 15 September 2020

\section{References}

Abdallah MMS, El-Bassiouny HMS, AbouSeeda MA (2019) Potential role of kaolin or potassium sulfate as anti-transpirant on improving physiological, biochemical aspects and yield of wheat plants under different watering regimes. Bull Natl Res Cent 43:134

Affi N, El Fadl A, El Otmani M, Benismail MC, Idrissi LM, Salghi R, El Mastor A (2012) Comparative effects of partial rootzone drying and deficit irrigation on physiological parameters of tomato crop. Der Pharma Chemica 4:2402-2407

Ahmad S, Raza MAS, Saleem MF, Zaheer MS, lqbal R, Haider I, Aslam MU, Ali M, Khan $\mathrm{IH}$ (2020) Significance of partial root zone drying and mulches for water saving and weed suppression in wheat. J.Anim.Plant.Sci. 30:154-162

Ahmadi SH (2009) Agronomic and physiological studies of partial root-zone drying and deficit irrigation on potato in different soil textures. Published Ph. D. Thesis, Department of Basic Sciences and Environment, Faculty of Life Sciences University of Copenhagen, Denmark, p 77

Ahmadi SH, Andersen MN, Plauborg F, Poulsen RT, Jensen CR, Sepaskhah AR, Hansen S (2010) Effects of irrigation strategies and soils on field grown potatoes: Gas exchange and xylem [ABA]. Agric Water Manag 97:1486-1494 
Ali HI, Ismail MR, Saud HM, Manan MM (2004) Effect of partial rootzone drying (PRD) on growth, water use efficiency (WUE) and yield of tomatoes grown in soilless culture.

Ali M, Jensen CR, Mogensen VO, Andersen MN, Henson IE (1999) Root signalling and osmotic adjustment during intermittent soil drying sustain grain yield of filed grown wheat. Field Crop Res 62:35-52

Alkhaldi A, Aldarir AN, Janat M, Wahbi A, Arslan A (2012) Effect of regulated deficit irrigation and partial root-zone drying on some quantitative indicators and the efficiency of adding nitrogen fertilizer to (Zea mays L.) by using n15 Isotope. Am-Eu J Agric Env Sci 12:1223-1235

Bahrun A, Jensen CR, Asch F, Mogensen VO (2002) Drought-induced changes in xylem pH, ionic composition, and ABA concentration act as early signals in field-grown maize (Zea mays L.). J Exp Bot 53:251-263

Bakht J, Shafi M, Yousaf M, Khan MA (2010) Effect of irrigation on physiology and yield of sunflower hybrids. Pak J Bot 42:1317-1326

Bauerle WL, Inman WW, Dudley JB (2006) Leaf abscisic acid accumulation in response to substrate water content: Linking leaf gas exchange regulation with leaf abscisic acid concentration. J Am Soc Hortic Sci 131:295-301

Benjamin JG, Nielsen DC (2006) Water deficit effects on root distribution of soybean, field pea and chickpea. Field Crop Res 97:248-253

Campos H, Trejo C, Pena Valdivia BC, Ramirez-Ayala C, Sanchez-Garcia P (2009) Effect of partial rootzone drying on growth, gas exchange, and yield of tomato (Solanum lycopersicum L.). Scientia Hortic. 120: 493-499.

Castillo EG, Tuong TP, Ismail AM, Inumbushi K (2007) Response to salinity in rice: Comparative effects of osmotic and ionic stresses. Plant Production Sci 10: $159-170$

Chaves MM, Oliveira MM (2004) Mechanisms underlying plant resilience to water deficits: prospects for water-saving agriculture. J Exp Bot 55:365-384

Comstock JP (2002) Hydraulic and chemical signaling in the control of stomatal conductance and transpiration. J Exp Bot 53:195-200

Costa JM, Ortuno MF, Chaves MM (2007) Deficit irrigation as a strategy to save water: physiology andpotential application to horticulture. J Integr Plant Biol 49:1421-1434

Davies WJ, Hartung W (2004) Has extrapolation from biochemistry to crop functioning worked to sustain plant production under water scarcity. In Proceeding of the fourth International crop Science Congress (Vol. 26, September).

Davies WJ, Wilkinson S, Loveys BR (2002) Stomatal control by chemical signaling and the exploitation of this mechanism to increase water use efficiency in agriculture. New Phytol 153:449-460

Davies WJ, Zhang JH (1991) Root signals and the regulation of growth and development of plants in drying soil. Ann Review Plant Physiol Plant Mol Biol 42:55-76

De la Hera ML, Romero P, Gomez-Plaza E, Martinez A (2007) Is partial root-zone drying an effective irrigation technique to improve water use efficiency and fruit quality in field-grown wine grapes under semiarid conditions? Agric Water Manag 87:261-274

Dodd IC (2003) Hormonal interactions and stomatal responses. J Plant Growth Regul 22:32-46

Dodd IC (2009) Rhizosphere manipulations to maximize 'crop per drop' during deficit irrigation. J Exp Bot 60:2454-2459

Dorji K, Behboudian MH, Zegbe-Domínguez JA (2005) Water relations, growth, yield, and fruit quality of hot pepper under deficit irrigation and partial root zone drying. Sci Hortic 104:137-149

Dos Santos TP, Lopes CM, Rodrigues ML, De Souza CR, Maroco JP, Pereira JS, Silva JR, Chaves MM (2003) Partial rootzone drying: effects on fruit growth and quality of field grown grapevines (Vitis vinifera). Funct Plant Biol 30:663-671

Dry PR, Loveys BR, During H (2000) Partial drying of the root-zone of grape. II. Changes in the pattern of root development. Vitis 39:9-12

Du T, Kang S, Sun J, Zhang X, Zhang J (2010). An improved water use efficiency of cereals under temporal and spatial deficit irrigation in north China. Agric Water Management. 97: 66-74.

Du T, Kang S, Zhang J, Li F (2008a). Water use and yield responses of cotton to alternate partial root-zonedrip irrigation in the arid area of northwest China. Irrig. Sci. 26: 147-159.

Du T, Kang S, Zhang J, Li F, Hu X (2006) Yield and physiological responses of cotton to partial root-zoneirrigation in the oasis field of northwest China. Agric. Water Management. 84: 41-52.

Du T, Kang S, Zhang J, Li F, Yan B (2008b) Water use efficiency and fruit quality of table grape under alternate partial root-zone drip irrigation. Agric. Water Management. 95: 659-668.
Du Toit PG, Dry PR, Loveys BR (2003) A preliminary investigation on partial root zone drying effects on grapevine performance, nitrogen assimilation and berry composition. South Afr J Enol Viticult 24:43-54

DUT KS, Zhang J, Li F, Hu X (2006) Yield and physiological responses of cotton to partial root-zone irrigation in the oasis field of northwest China. Agric Water Manag 84:41-52

English MJ, Musick JT, Murty WN (1990) Deficit irrigation. Management of farm irrigation systems (Hoffman, G.J., Howell, T.A., and Solomon, K.H., Editors). ASAE Monograph no. 9. American Society of Agricultural Engineers publisher, 1020p.

Ezzo MI, Mohamed AS, Glala AA (2020) Utilization of grafting technique for sustaining cantaloupe productivity and quality under deficit irrigation water. Bull Natl Res Cent 44:23

Fereres E, Soriano MA (2007) Deficit irrigation for reducing agricultural water use. J Exp Bot 58:147-159

Fernandez JE, Diaz-Espejo A, Infante JM, Duran P, Palomo MJ, Chamorro V, Giron IF, Villagarica $L$ (2006) Water relations and gas exchange in olive trees under regulated deficit irrigation and partial root-zone drying. Plant Soil 284:273-291

Geerts S, Raes D (2009) Deficit irrigation as an on-farm strategy to maximize crop water productivity in dry areas. Agric Water Manag 96:1275-1284

Gencoglan C, Altunbey H, Gencoglan S (2006) Response of green bean (P-vulgaris L.) to subsurface drip irrigation and partial root zone drying irrigation. Agric. Water Manage 84:274-280

Gholipoor M, Sinclair TR, Raza MAS, Loffler C, Cooper M, Messina CD (2013) Maize hybrid variability for transpiration decrease with progressive soil drying. J Agron Crop Sci 199:23-29

Glinka Z (1980) Abscisic acid promotes both volume flow and ion release to the xylem in sunflower roots. Plant Physiol 65:537-540

Gong DZ, Wang JP, Kang SZ (2001) Variation of root and trunk sap flow rate under different soil water wetting patterns. Transac Chin Soc Agric Eng 17: 34-38

Grimes DW, Walhood VT, Dickens WL (1968) Alternate-furrow irrigation for San Joaquin valley cotton. Calif Agric 22:4-6

Guang-Cheng S, Zhan-Yua Z, Nac L, Shuang-Ena Y, Weng-Ganga X (2008) Comparative effects of deficit irrigation (DI) and partial rootzone drying (PRD) on soil water distribution, water use, growth and yield in greenhouse grown hot pepper. Sci Hortic 119:11-16

Huffaker R, Hamilton J (2007) Conflict. In: Irrigation of Agricultural crops (Lascano, R.J., and Sojka,R.E. eds.), 2ndedition, Agronomy Monograph no. 30. ASACSSA-SSSA publishing, 664p.

Ibrahim MA, Emara TK (2010) Water saving under alternative furrows surface irrigation in clay soils of north Nile delta. In: Fourteenth International Water Technology Conference (IWTC), Cairo, pp 21-23

lqbal R, Andersen MN, Raza MAS, Rashid MA, Ahmad S (2019a) Physiological manipulation and yield response of wheat grown with split root system under deficit irrigation. Pak J Agric Res 32:514-526

lqbal R, Muhammad ASR, Muhammad FS, Imran HK, Salman A, Muhammad SZ, Muhammad U, Imran H (2019b) Physiological and biochemical appraisal for mulching and partial rhizosphere drying of cotton. J Arid Land 11:785-794

Iqbal R, Raza MAS, Valipour M, Saleem MF, Zaheer MS, Ahmad S, Nazar MA (2020) Potential agricultural and environmental benefits of mulches-a review. Bull Natl Res Cent 44:1-16

Jones CA, Jacobesen JS, Wraith JM (2003) The effects of P fertilization on drought tolerance of Malt Barley. Western Nutrient Management Conference. Salt Lake City, UT. 5:88-93

Jovanovic Z, Stikic R, Vucelic-Radovic B, Paukovic M, Brocic Z, Matovic G, Rovcanin S, Mojevic M (2010) Partial root-zone drying increases WUE, N and antioxidant content in field potatoes. Eur J Agric 33:124-131

Kader MA, Singha A, Begum MA, Jewel A, Khan FH, Khan NI (2019) Mulching as water-saving technique in dry-land agriculture. Bull Nat Res Cent 43:1-6

Kaman H, Kirda C, Cetin M, Topcu S (2006) Salt accumulation in the root zones of tomato and cotton irrigated with partial root-drying technique. Irrig Drain 55 533-544

Kang S, Zhang L, Hu X, Li Z, Jerie P (2001) An improved water use efficiency for hot pepper grown under controlled alternate drip irrigation on partial roots. Sci Hortic 89:257-267

Kang SZ, Hu X, Goodwin I, Jerie P (2002) Soil water distribution, water use, and yield response to partial root zone drying under a shallow groundwater table condition in a pear orchard. Scientia Hortic.92: 277-291.

Kang SZ, Hu X, Jerie P, Zhang JH (2003). The effects of partial rootzone drying on root, trunk sap flow and water balance in an irrigated pear (Pyrus communis L.) orchard. J. Hydro. 280: 192-206. 
Kang SZ, Liang ZS, Hu W, Zhang JH (1998) Water use efficiency of controlled alternate irrigation on root divided maize plants. Agric Water Manag 38:6976

Kang SZ, Liang ZS, Pan YH, Shi PZ, Zhang JH (2000a) Alternate furrow irrigation for maize production in an arid area. Agric Water Manag 45:267-274

Kang SZ, Shi P, Pan YH, Liang ZS, Hu XT, Zhang J (2000b) Soil water distribution, uniformity and water-use efficiency under alternate furrow irrigation in arid areas. Irrig Sci 19:181-190

Kang SZ, Zhang JH (2004) Controlled alternate partial root-zone irrigation: its physiological consequences and impact on water use efficiency. J Exp Bot $55: 2437-2446$

Khan AJ, Azam F, Ali A (2010) Relationship of morphological traits and grain yield in recombinant inbreed wheat lines grown under drought conditions. Pak J Bot 42:259-267

Kirda C, Cetin M, Dasgan Y, Topcu S, Kaman H, Ekici B, Derici MR, Ozguven Al (2004) Yield response of greenhouse grown tomato to partial root drying and conventional deficit irrigation. Agric Water Manag 69:191-201

Kirda C, Topcu S, Kaman H, Ulger AC, Yazici A, Cetin M, Derici MR (2005) Grain yield response and $\mathrm{N}$-fertiliser recovery of maize under deficit irrigation. Field Crop Res 93:132-141

Kriedmann PE, Goodwin I (2003) Regulated deficit irrigation and partial root-zone drying. Irrigation insights no. 4. Land and Water Australia, Canberra, p 102

Lascano RJ, Sojka RE (2007) Preface. In: Irrigation of agricultural crops (Lascano, R. J., and Sojka, R.E. eds.), 2nd edition, Agronomy Monograph no. 30. ASA-CSSASSSA publishing, 664p.

Leib BG, Caspari HW, Redulla CA, Andrews PK, Jabro J (2006) Partial root-zone drying and deficit irrigation of 'Fuji' apples in a semi-arid climate. Irrig Sci 24 : 85-99

Liu F, Andersen MN, Jacobsen SE, Jensen CR (2005a) Stomatal control and water use efficiency of soybean (Glycine max L.) during progressive soil drying. Environ Exp Bot 54:33-40

Liu F, Jensen CR, Andersen MN (2003) Hydraulic and chemical signals in the control of leaf expansion and stomatal conductance in soybean exposed to drought stress. Funct Plant Biol 30:65-73

Liu F, Jensen CR, Andersen MN (2005b) A review of drought adaptation in crop plants: changes in vegetative and reproductive physiology induced by ABAbased chemical signals. Aust J Agric Res 56:1245-1252

Liu F, Jensen CR, Shahnazari A, Andersen MN, Jacobsen SE (2005c) ABA regulated stomatal control and photosynthetic water use efficiency of potato (Solanum tuberosum L.) during progressive soil drying. Plant Sci 168:831-836

Li F, Liang J, Kang Sh, Zhang J (2007). Benefits of alternate partial root-zone irrigation on growth, water and nitrogen use efficiencies modified by fertilization and soil water status in maize. Plant and Soil. 295: 279-291.

Liu F, Shahnazari A, Andersen MN, Jacobsen SE, Jensen CR (2006a) Physiological responses of potato (Solanum tubersum $\mathrm{L}$.) to partial root-zone drying: ABA signaling, leaf gas exchange, and water use efficiency. J Exp Bot 57:3727-3735

Liu F, Shahnazari A, Andersen MN, Jacobsen SE, Jensen CR (2006b) Effects of deficit irrigation (DI) and partial root drying (PRD) on gas exchange, biomass partitioning, and water use efficiency in potato. Sci Hortic 109:113-117

Liu F, Song R, Zhang X, Shahnazari A, Andersen MN, Plauborg F, Jacobsen SE, Jensen CR (2008) Measurement and modeling of ABA signaling in potato (Solanum tuberosum L.) during partial root-zone drying. Environ Exp Bot 63: 385-391

Loveys BR, Stoll M, Dry PR, McCarthy MG (2000) Using plant physiology to improve the water use efficiency of horticultural crops. Acta Hortic 537:187-197

Mingo DM, Theobald J, Bacon MA, Davies WJ, Dodd IC (2004) Biomass allocation in tomato (Lycopersicon esculentum) plants grown under partial root zone drying: enhancement of root growth. J Func Plant Biol 31:971-978

Morison JIL, Baker NR, Mullineaux PM, Davies WJ (2008) Improving water use in crop production. Phil Transac Royal Soc (London) B 363:639-658

Mousavi-Avval SH, Rafiee S, Jafari A, Mohammadi A (2011) Energy flow modeling and sensitivity analysis of inputs for canola production in Iran. J Clean Prod 19:1464-1470.

Musick JT, Dusek DA (1982) Skip-row planting and irrigation of graded furrows. Transact ASAE 25:82-87

Nasrullah M, Khan MB, Ahmad R, Ahmad S, Hanif M, Nazeer W (2011) Sustainable cotton production and water economy through different planting methods and mulching techniques. Pak J Bot 43:1971-1983

North GB, Nobel PS (1991) Changes in hydraulic conductivity and anatomy caused by drying and rewetting roots of Agave-Deserti (Agavaceae). Am J Bot 78:906-915
Pandias BJ, Muthukrishmanard P, Rajasekaran S (1992) Efficiency of different irrigation methods and regimes in sugarcane. Ind Sugar 42:215-219

Poni S, Tagliavini M, Neri D, Scudellari D, Toselli M (1992) Influence of root pruning and water-stress on growth and physiological factors of potted apple, grape, peach and pear trees. Sci Hortic 52:223-236

Posadas A, Rojas G, Malaga M, Mares V, Quiroz RA (2008) Partial root zone drying: an alternative irrigation management to improve the water use efficiency of potato crops, International Potato Center (CIP), 2008-2 working paper, ISBN978- 92-9060-360-3.

Rashid MA, Zhang X, Andersen MN, Olesen JE (2019) Can mulching of maize straw complement deficit irrigation to improve water use efficiency and productivity of winter wheat in North China Plain? Agric Water Manag 213:1-11

Raza MAS, Ahmad S, Saleem MF, Khan IH, lqbal R, Zaheer MS, Haider I, Ali M (2017) Physiological and biochemical assisted screening of wheat varieties under partial rhizosphere drying. Plant Physiol Biochem 116: 150-166

Raza MAS, Saleem MF, Anjum SA, Khaliq T, Wahid MA (2012c) Foliar application of potassium under water deficit conditions improved the growth and yield of wheat (Triticum aestivum L.). J. Animal Plant Sci 22:431-437

Raza MAS, Saleem MF, Ashraf MY, Ali A, Asghar HN (2012b) Glycine betaine applied under drought improved the physiological efficiency of wheat (Triticum aestivum L.). Plant Soil Environ 31:67-71

Raza MAS, Saleem MF, Khan IH, Jamil M, ljaz M, Khan MA (2012a) Evaluating the drought stress tolerance efficiency of wheat (Triticum aestivum L.) cultivars. Russ J Agric Soc-Eco Sci 12:41-46

Rodrigues ML, Santos TP, Rodrigues AP, de Souza CR, Lopes CM, Maroco JP, Pereira JS, Chaves MM (2008) Hydraulic and chemical signalling in the regulation of stomatal conductance and plant water use in field grapevines growing under deficit irrigation. Funct Plant Biol 35:565-579

Sadak MS, Abdalla AM, Abd Elhamid EM (2020) Role of melatonin in improving growth, yield quantity and quality of Moringa oleifera L. plant under drought stress. Bull Natl Res Cent 44:18

Sadak MS, El-Bassiouny HMS, Dawood MG (2019) Role of trehalose on antioxidant defense system and some osmolytes of quinoa plants under water deficit. Bull Natl Res Cent 43:5

Sadras VO (2009) Does partial root-zone drying improve irrigation water productivity in the field? A meta-analysis. Irrig Sci 27:183-190

Saeed H, Grove IG, Kettlewell PS, Hall NW (2008) Potential of partial root zone drying as an alternative irrigation technique for potatoes (Solanum tuberosum L). Annal Applied Botany 152:71-80

Samadi A, Sepaskhah AR (1984) Effects of alternate furrow irrigation on yield and water use efficiency of dry beans. Iran Agric Res 3:95-115

Schahbazian N, Iran-Nejad H (2006) The effects of different mulch types and irrigation intervals on cotton yield. Die Boden 57:765-766

Schneider AD, Howell TA (1999) LEPA and spray irrigation for grain crops. J Irrig Drain Eng 125:167-172

Sepaskhah AR, Ghasemi MM (2008) Every-other furrow irrigation with different irrigation intervals for sorghum. Pak J Biol Sci 11:1234-1239

Sepaskhah AR, Hosseini SN (2008) Effects of alternate furrow irrigation and nitrogen application rates on winter wheat (Triticum aestivum L.) yield, waterand nitrogen-use efficiencies. Plant Prot Sci 11:250-259

Sepaskhah AR, Kamgar-Haghighi AA (1997) Water use and yields of sugarbeet grown under every-other furrow irrigation with different irrigation intervals. Agric Water Manag 34:71-79

Sepaskhah AR, Khajehabdollahi MH (2005) Alternate furrow irrigation with different irrigation intervals for maize (Zea mays L.). Plant Prot Sci 8:592-600

Sepaskhah AR, Kheradnam M (1977) Alternate furrow irrigation for sugarbeet. Res Center Bull Faculty Agric Shiraz Univ 4:108-110

Sepaskhah AR, Parand AR (2006) Effects of alternate furrow irrigation with supplemental every-furrow irrigation at different growth stages on the yield of maize (Zea mays L.). Plant Prot Sci 9:415-421

Sepaskhah AR, Sichani SA (1976) Evaluation of subsurface irrigation spacings for bean production. Can Agric Eng 18:23-26

Shahnazari A, Ahmadi SH, Laerke PE, Liu F, Plauborg F, Jacobsen SE, Jensen CR, Andersen MN (2008) Nitrogen dynamics in the soil-plant system under deficit and partial root-zone drying irrigation strategies in potatoes. Eur J Agric 28:65-73

Shahnazari A, Liu F, Andersen MN, Jacobsen SE, Jensen CR (2007) Effects of partial root-zone drying on yield, tuber size and water use efficiency in potato under field conditions. Field Crop Res 100:117-124

Shani-Dashtgol A, Jaafari S, Abbasi N, Malaki A (2006) Effect of alternate furrow irrigation (PRD) on yield quantity and quality of sugarcane in southern farm 
in Ahvaz. Proceeding of national conference on Irrigation and Drainage Networks Management. Shahid Chamran University of Ahvaz, pp 565-572

Sinclair TR (2005) Theoretical analysis of soil and plant traits influencing daily plant water flux on drying soils. J Agron 97:1148-1152

Sleper DA, Fales SL, Collins ME (2007) Foreword. In: Irrigation of agricultural crops (R.J. Lascano and R.E. Sojka, eds.), $2^{\text {nd }}$ edition, Agronomy Monograph no. 30.

Songsri P, Jogloy S, Vorasoot N, Akkasaeng C, Patanothai A, Holbrook CC (2008) Root distribution of drought-resistant peanut genotypes in response to drought. J Agric Crop Sci 194:92-103

Stikic R, Jovanovic Z, Prokic L (2014) Mitigation of plant drought stress in a changing climate. Bot Ser 38:35-42

Stikic R, Popovic S, Srdic M, Savic D, Jovanovic Z, Prokic LJ, Zdravkovic J (2003) Partial root drying (PRD): a new technique for growing plants that saves water and improves the quality of fruit. Bulg J Plant Physiol 2003:164-171

Stoll M, Loveys B, Dry P (2000) Hormonal changes induced by partial root-zone drying of irrigated grapevine. J Exp Bot 51:1627-1634

Taiz L, Zeiger E (2006) Journal of Plant physiology. Sinauer Associates, Inc., Publishers, $\mathrm{p} 764$

Tang LS, Li Y, Zhang J (2005) Physiological and yield responses of cotton under partial rootzone irrigation. Field Crop Res 94:214-223

Tardieu F, Davies WJ (1993) Integration of hydraulic and chemical signalling in the control of stomatal conductance and water status of droughted plants. Plant Cell Environ 16:341-349

Tawfik RS, El-Mouhamady ABA (2019) Molecular genetic studies on abiotic stress resistance in sorghum entries through using half diallel analysis and intersimple sequence repeat (ISSR) markers. Bull Natl Res Cent 43:117

Thompson AJ, Andrews J, Mulholland BJ, McKee JMT, Hilton HW, Horridge JS, Farquhar GD, Smeeton RC, Smillie IRA, Black CR, Taylor IB (2007) Overproduction of Abscisic acid in tomato increases transpiration efficiency and root hydraulic conductivity and influences leaf expansion. J Plant Physiol 143:1905-1917

Topcu S, Kirda C, Dasgan Y, Kaman H, Cetin M, Yazici A, Bacon MA (2007) Yield response and $\mathrm{N}$ fertiliser recovery of tomato grown under deficit irrigation. Eur J Agron 26:64-70

Wahbi S, Wakrim R, Aganchich B, Tahi H, Serraj R (2005) Effects of partial rootzone drying (PRD) on adult olive tree (Olea europaea) in field conditions under arid climate I. Physiological and agronomic responses. Agric Ecosyst Environ 106:289-301

Wakrim R, Wahbi S, Tahi H, Aganchich B, Serraj R (2005) Comparative effects of partial root drying (PRD) and regulated deficit irrigation (RDI) on water relations and water use efficiency in common bean (Phaseolus vulgaris L.). Agric Ecosyst Environ 106:275-287

Wang FX, Kang Y, Liu SP (2006) Effects of drip irrigation frequency on soil wetting pattern and potato growth in North China Plain. Agric Water Manag 79:248-264

Wang H, Liu F, Andersen MN, Jensen CR (2009) Comparative effects of partial root-zone drying and deficit irrigation on nitrogen uptake in potatoes (Solanum tuberosum L.). Irrig Sci 27:443-447

Wilhite DA, Smith MB (2005) Drought as Hazard: Understanding the Natural and Social Context. In: Wilhite DA (ed) Drought and Water Crises: Science, Technology, and Management Issues. CRC Press, U.S, pp 3-29

Wilkinson S (1999) pH as a stress signal. Plant Growth Regul 29:87-99

Yazar A, Gokçel F, Sezen MS (2009) Corn yield response to partial rootzone drying and deficit irrigation strategies applied with drip system. Plant Soil Environ 55:494-503

Zegbe JA, Behboudian MH (2008) Plant water status, $\mathrm{CO}_{2}$ assimilation, yield, and fruit quality of 'Pacific Rose TM' apple under partial rootzone drying. Adv Hortic Sci 22:27-32

Zegbe JA, Behboudian MH, Clothier BE (2004) Partial rootzone drying is a feasible option for irrigating processing tomatoes. Agric Water Manag 68:195-206

Zegbe JA, Behboudian MH, Clothier BE (2006) Responses of 'Petopride' processing tomato to partial rootzone drying at different phenological stages. Irrig Sci 24:203-210

Zegbe JA, Behboudian MH, Clothier BE (2007) Response of tomato to partial rootzone drying and deficit irrigation. Rev Fitotec Mex 30:125-131

Zhang H (2003) Improving water productivity through deficit irrigation: Examples from Syria, the north China Plain and Oregon, USA. In: Kijne JW, Barker R, Molden D (eds) Water Productivity in Agriculture: Limits and Opportunities for Improvement. CABI publishing, p 332

\section{Publisher's Note}

Springer Nature remains neutral with regard to jurisdictional claims in published maps and institutional affiliations.

\section{Submit your manuscript to a SpringerOpen ${ }^{\circ}$ journal and benefit from:}

- Convenient online submission

- Rigorous peer review

- Open access: articles freely available online

- High visibility within the field

- Retaining the copyright to your article

Submit your next manuscript at $\boldsymbol{\nabla}$ springeropen.com 